Reunifying and separating: An analysis of residential arrangements of migrant couples in

\title{
Ouagadougou, Burkina Faso
}

Marie-Laurence FLAHAUX

Madeleine WAYACK PAMBE

Abdramane SOURA

Yacouba COMPAORE

Souleymane SANOGO

FLAHAUX, M.-L., WAYACK-PAMBE, M., SOURA, A., SANOGO, S., COMPAORE, Y. (2020), "Reunifying and separating: An analysis of residential arrangements of migrant couples in Ouagadougou, Burkina Faso", Population, Space and Place, 26 (4), 1-16, DOI: 10.1002/psp.2287.

\section{Abstract:}

This paper offers new evidence on the residential arrangements of couples in the context of migration and urbanisation in Africa, focusing on the case of Ouagadougou, Burkina Faso's capital city. We use a mixed-methods approach, combining data from a survey on the family histories of migrants merged with data from the Ouagadougou Health and Demographic Surveillance System and qualitative interviews. The objective is to analyse how the migrants themselves perceive "living apart together", the extent of this phenomenon, its timing, and the factors influencing it. The longitudinal nature of our data specifically allows for the study of the drivers of couple reunification in Ouagadougou and of the physical separation of partners, whereby one goes to live away from Ouagadougou. Our results reveal that $25 \%$ of migrants in a union had a partner living outside Ouagadougou in 2015, and that the residential arrangements of such couples were associated with gender relations, family cycle, and integration into the city.

Key words:

residential arrangements, migration, urbanisation, family reunification, mixed methods, living apart together 


\section{Introduction}

Migration is regularly associated with the fracturing of families (Toyota, Yeoh, \& Nguyen, 2014). The topic of African families where the partners live at a distance from each other has been studied in a transnational context, particularly between West Africa and Europe (Baizán et al., 2014; Barou, 2001; Caarls \& de Valk, 2017; Beauchemin et al., 2015; Mazzucato et al. 2015). Among other things, these studies on "living apart together" (LAT) have highlighted the role of borders. African families dispersed in different places have also been investigated in the context of free circulation within sub-Saharan Africa, in particular in Central, Eastern and Southern Africa (Comhaire-Sylvain, 1968; Amoateng \& Richter, 2017; Camlin et al., 2014; Hosegood et al., 2009). These studies have revealed the lasting influence of restrictions on migration during the colonial period and under apartheid in South Africa. There has been less research on dispersed families within West Africa, where, as shown in the case of Burkina Faso (Upper Volta), mobility was less constrained during the colonial period and families could migrate together, contrarily to the situation in Southern Africa (Gregory et al., 1989; Zongo, 2003).

In the context of urbanisation in Africa, it is often assumed that men migrate first to the capital city in order to diversify the family's income and mitigate against risks in their place of origin, and that women and children follow them later (Fargues, 1989). However, the residential arrangements of African migrant couples are poorly understood, particularly in West Africa, where "multi-local" households are not uncommon. In this context, the way in which couples with one of the partners located in a city are compelled or choose to live in different localities rather than together has been understudied. Little is known about the conditions under which pioneer migrants may subsequently be joined by their partner, or when the partners in a union may start to live in different localities because one of them leaves the place of residence. There is a need to explore the phenomenon of couples who "live apart together": what is the extent of this family arrangement? Who does it affect? Why does it happen? How long does it last? Yet there is a lack of data available about migration and family histories of migrants. On the one hand, cross-sectional household surveys and censuses do not usually collect information about geographically dispersed families (Bennett et al., 2015) or couples. On the other hand, health and demographic surveillance systems do normally not collect information about detailed life trajectories of individuals or about the migration history of their partner.

This paper offers new evidence on these questions in the context of Ouagadougou, Burkina Faso's capital city, thanks to data from a survey carried out in 2015 on the family histories of migrants merged with data from the Ouagadougou Health and Demographic Surveillance System (Ouaga HDSS) and qualitative interviews. The Ouaga HDSS was established with the purpose of collecting empirical data about socio-demographic change. It routinely registers all "vital events" and other information-such as unions and migration events-on a population of approximately 80,000 people in five neighbourhoods in the periphery of Ouagadougou (Rossier et al., 2012).

Like other African cities, one of the key challenges faced by Ouagadougou-and one that will intensify in the coming decades - is population growth, due to both natural growth and positive net migration (more in-migration than out-migration). A better understanding of family and migration dynamics is crucial for the development of appropriate urban policies in response to this growth. 
The objective of this article is to study the residential arrangements of couples where one but not necessarily both partners are migrants and live in Ouagadougou, whether they are from a rural or urban area in Burkina Faso or from abroad. We aim to better understand how the migrants themselves perceive "living apart together", the extent of this phenomenon, its timing, and the factors influencing it. We examine couples' residential arrangements not only at one particular moment but also over time. Indeed, the longitudinal nature of our data allows us to particularly investigate the drivers of couples' reunification (where one migrant is joined in Ouagadougou by his/her partner who had been living elsewhere) and physical separation (when a migrant living with his/her partner in Ouagadougou is left behind when the partner leaves the city). ${ }^{1}$

The paper is structured as follows. We first give some contextual background on urbanisation and the draw of Ouagadougou. Then we review the literature relating to couples living "apart together" with an emphasis on those related to the context of African migration. We follow that with a description of the qualitative and quantitative data used in the study as well as the methods of analysis adopted. Finally, we present the results to show the extent of the phenomenon of "living apart together", the insights gained from the qualitative analysis, and the factors at play in couple reunification and physical separation.

\section{Urbanisation and the draw of Ouagadougou}

Ouagadougou, the capital of Burkina Faso, exemplifies the rapid growth found in most West African cities. In 1990 it had 537,000 inhabitants, but this number had soared to 2.7 million by 2015 and is expected to reach 5.8 million by 2030 (United Nations, 2014). This increase is due to both natural population growth (high fertility coinciding with declining mortality) and positive net migration (more in-migration than out-migration) (Soura, 2014). Migrants arriving in Ouagadougou are mainly from Burkina Faso's rural areas, but there has been an increase in arrivals from Côte d'Ivoire since the 1990s due to political and economic crisis in that country, historically a destination country for Burkinabe migrants (Bredeloup, 2006). The migrant population in Ouagadougou is young and migrants often live on the city's periphery, as revealed by a 2009 survey (Delaunay \& Boyer, 2017a). For many migrants, especially from rural areas, the capital is synonymous with opportunities for work and social mobility (Soura, 2014), which contributes to its attraction as a destination. However, in reality, migration to the city does not always go hand in hand with an improvement in living conditions.

Ouagadougou has faced problems of unemployment and limited opportunity in formal sectors. Due to persistent poverty in some urban areas and to problems specific to the urban environment such as housing density and shrinking social support networks, living conditions may be worse in some urban neighbourhoods in the capital city than in rural areas (Rossier et al., 2012). In 2009 in Ouagadougou only 23\% of houses had electricity and $25 \%$ had access to running water (Delaunay \& Boyer, 2017a). In 2009, a quarter of the population lived in unincorporated or informal neighbourhoods (Boyer, 2010). These neighbourhoods are unplanned and spontaneous settlements that are mainly located on the periphery of the city and in which people live in slum-like conditions, often with little or no

\footnotetext{
${ }^{1}$ In this paper "physical separation" does not refer to divorce or end of union.
} 
access to public utilities. Despite such obvious poverty, these urban spaces are seen as gateways to greater prosperity as they offer hope for job opportunities and access to basic services, in particular health care and education (Soura, 2014), which may ensure families a better future.

This paper studies the family arrangements of migrants in this context, focusing on the residential arrangements of couples (but not of their children or extended families), where at least one of them lives in Ouagadougou.

\section{Previous research on couples living "apart together"}

The topic of partners living in different locations has been empirically addressed in the context of African international migration through the analysis of qualitative (Barou, 2001; Quiminal, 1995) and quantitative data (Caarls et al., 2018; Caarls \& de Valk, 2017; Beauchemin et al., 2015; Baizán et al., 2014; Mazzucato et al., 2015; Nappa, 2017). ${ }^{2}$ These studies, which mostly focus on families spread between West/Central Africa and Europe, specifically examine couple arrangements and factors at play in couple reunification.

The topic of trans-local families where the migration is internal has also been examined in the literature, more specifically in the context of Central, Eastern and Southern Africa. While some of these studies interrogate the link between the mobility of one of the partners and risky sexual behaviours (Vissers et al., 2008; Kwena et al., 2013; Lurie, 2006), others highlight that migrants' family arrangements are the result of past and present political, economic, and social realities. Some studies point out the role of restrictions on migration to cities during the colonial period. In the Congo, during that period, migrant workers, almost exclusively men, lived apart from their families because the colonial administration prohibited them from moving to the city with their families and settling permanently there (Comhaire-Sylvain, 1968, cited by Nappa, 2017). After independence, the removal of this constraint led to strong urban migration in the form of family reunification (Lututala, 1987; Zamwangana, 2005). In South Africa, many African married couples cannot live together due to housing contraints (Amoateng \& Richter, 2017), but mobility has also been strongly influenced by apartheid-induced laws (Hosegood et al., 2009). During apartheid, African male workers were temporary residents of the country's major towns and cities and could not live in these locations with their family members, who were in most cases left behind in the rural areas (Amoateng \& Richter, 2017; Camlin et al., 2014). Studying the case of KwaZulu-Natal in South Africa, Hosegood et al. (2009) show that apartheid policies have had a lasting influence on the residential arrangements of couples due to the barriers to free movement of families and the legacy of labour migration. They write that, consequently, "cohabitation is not seen as a necessary signifier of either a marital or non-marital partnership" (p.12). Their quantitative study shows that $35 \%$ of married women had a noncohabiting spouse.

Mobility in Burkina Faso during the colonial period was shaped differently. Forced labour migration did not take place with the same intensity, and the mobility of workers became

\footnotetext{
${ }^{2}$ A recent special issue of Population, Space and Place, entitled "Transnational families: Cross-country comparative perspectives", was published in October 2018 (vol. 24, issue 7) and analysed several African datasets.
} 
more voluntary and free, as Gregory et al. (1989) indicate. Many Burkinabe families settled in Côte d'Ivoire during colonisation (Zongo, 2003). Some research about Burkinabe migration in the post-colonial period mentions the temporary dispersal of families following the deterioration of the economy and of the status of foreigners in Côte d'Ivoire, as well as the crisis in that country during which families decided to evacuate women and children first (Blion, 1992; Ouedraogo, 1993; Bredeloup, 2006). Analysing female migration between Burkina Faso and Côte d'Ivoire, Néya (2016b) also writes that families develop residential strategies, and were doing so even before the crisis in Côte d'Ivoire: polygamous husbands could send some of their wives over the border in order to strengthen their links in several locations and establish transnational family lives. Another study on social networks in Ouagadougou suggests that husbands migrating out of the capital city may leave their wives there while migrating elsewhere, based on the fact that women in the city receive more often support than men from migrants who have left the city (Delaunay \& Boyer, 2017b).

Besides historical justifications, economic justifications are often given in the literature to explain the phenomenon of couples that live apart together. On the one hand, the neoclassical perspective supports that migrants would be interested in reunification only when bringing the spouse to the place of destination would maximise the gains (for example, if the spouse could find a job) and minimise living costs for the family (Beauchemin et al., 2015). On the other hand, under the new economics of labour migration (NELM), migration aims at diversifying incomes, and there is a strategic interest in families remaining divided, since reuniting in the precarious environment of the place of destination can increase the vulnerability of the whole family (Beauchemin et al., 2015). In this way, empirical evidence from sub-Saharan Africa shows that families may be temporarily dispersed in order to diversify incomes (Findley, 1997; Pilon \& Vignikin, 2006; Guilmoto \& Sandron, 2000), and the international LAT literature highlights that family reunification depends on the socioeconomic integration of the migrant partner in the destination country in relation to his/her housing, professional and financial situation-the very criteria that form the basis for reunification requirements under family reunification laws (Bledsoe \& Sow, 2011; Baizán et al., 2014; González-Ferrer, 2011; Ambrosini, 2008; Beauchemin et al., 2015).

More recently, the literature on couples living across borders has paid particular attention to social logics (Baizán et al., 2014; Nappa, 2017) in explaining family reunification. It highlights the role of the social context in the place of origin, including gender issues, and the importance of individual characteristics of the partners and their stage in the family cycle (Caarls \& Mazzucato, 2016). The level of education, the place of origin, the presence of children, or the union's duration may be important in explaining why partners live together or not.

\section{Methodology}


This research was carried out as part of the Family Strategies of Migrants in Ouagadougou project, $^{3}$ which collected and analysed quantitative and qualitative data among migrants in Ouagadougou in order to better understand how Burkinabe articulate their migration and family trajectories. We consider that a "migrant" is a person born outside Ouagadougou who has lived in Ouagadougou for at least six months; and we define "union" as a partnership between a man and a woman, whether or not they have celebrated a religious, traditional and/or civil marriage, and whether or not they are cohabiting.

\section{- A mixed-methods approach}

We use a mixed-methods approach, combining quantitative and qualitative data, to examine the residential arrangements of migrant couples in Ouagadougou in all their complexity. These data are complementary. Quantitative data are used to document the extent of the phenomenon of couples living apart together and the timing and duration of couple reunification in the city and its physical separation. Qualitative interviews are used to explore the migrants' general perceptions of living apart or together in Ouagadougou and the reasons for their family arrangements, thus allowing us to put forward research hypotheses regarding the factors at play in these arrangements and in events of couple reunification and physical separation. Finally, quantitative data are used to study the factors influencing couples' strategies and arrangements.

\section{- Quantitative data}

We use data from the Ouagadougou Health and Demographic Surveillance System (Ouaga HDSS), which has collected data on living conditions and events in the lives of all inhabitants in five formal and informal neighbourhoods on the northern periphery of the city every year since 2008. Approximately 80,000 individuals are tracked in this way. The primary purpose of this surveillance system is to understand the problems of the urban poor, with a particular focus on their access to health services (Rossier et al., 2012). As part of the longitudinal study, it has gathered data on the changing structure of families, including the coming and goings of household members, and their living conditions. The Ouaga HDSS tracks all residents living in the neighbourhoods surveyed. A resident is defined as a person who has lived for more than six months in a unit of collective habitation (a building which is either enclosed or belonging to the same owner). Migrants are defined as people born outside Ouagadougou, who have lived for at least six months in Ouagadougou, and who come from a rural area, an urban area, or another country. The Ouaga HDSS dataset gives information on their socio-demographic characteristics, migration, union(s), children, housing situation, work situation, and living conditions over time. ${ }^{4}$ However, the Ouaga HDSS does not collect information on a partner's place(s) of residence since the beginning of the union or on a man's children when the births occur outside the area covered by the Ouaga HDSS.

In order to fill this gap, we carried out an additional face-to-face survey in 2015 on the family histories of migrants included in the Ouaga HDSS aged 15 years or more and who

\footnotetext{
${ }^{3}$ This project was realised between 2015 and 2017 in partnership with the International Migration Institute at the University of Oxford and the Higher Institute for Population Sciences at the University of Ouaga I - Prof. Joseph Ki-Zerbo, with the support of the Swiss Agency for Development and Cooperation.

${ }^{4}$ Not all information is collected in every survey round.
} 
arrived in Ouagadougou between 2008 and 2015, in order to obtain information on their partner's and children's migration histories ${ }^{5}$. We defined the migrant's partner as the person with whom the migrant declared being in a union/couple, regardless of whether one or more wedding ceremonies have taken place or whether there has been cohabitation. The survey was conducted alongside the eighth Ouaga HDSS data collection round. Among the individuals who were eligible to complete the survey, 88 percent responded, which provided a data set with information on a total of 4,587 individuals. In order to take into account the significant differences between respondents and non-respondents, we adopted a missing data strategy and computed weights based on variables associated to non-responses (age, educational level, place of origin and type of neighbourhood). Normalised weights were used in all the analyses (Raghunathan, 2004). ${ }^{6}$

The questionnaire mainly focused on the migrants' family histories (union and children). Regarding past and current union(s), information was collected-among other things-on a union's rank, the year it started, the year it ended (if over), and the partner's place of residence at the beginning of the union and at the time of the survey. Moreover, where the partner was not living in Ouagadougou at the start of the union, it was asked whether he/she had previously lived in Ouagadougou (for at least 6 months) and, if yes, where he/she came from, when he/she had arrived in Ouagadougou, and, in case of departure, when he/she left the city (for at least 6 months). If the partner was living in Ouagadougou when the union was formed, information was collected about whether or not he/she had since left the city (for at least 6 months) and, if yes, when this departure took place and when he/she returned (if indeed they had done so).

We merged the longitudinal data on migrants in the Ouaga HDSS with that collected in this additional survey. Time-varying variables were created on the migrant's place of residence (in Ouagadougou or elsewhere), the partner's place of residence (in Ouagadougou or elsewhere), whether the migrant was in a union, and whether the partner was in a union. We retained only the years where migrants were in a union and lived in Ouagadougou between 2008 and 2015 (because the Ouaga HDSS started in 2008). Then, we created the variables on the events of couple reunification and physical separation. In 39 cases out of 297 , couple reunification occurred the year of the union. We decided to assume that men were more likely than women to reunify with their partner in the city when the union and the reunification happened in the same year and to consider that there is couple reunification only when the migrant is a man. ${ }^{7}$ Thanks to the longitudinal nature of the data, we are able to know not only the migration trajectories of both the migrant and his/her partner, but also the potential factors influencing their family arrangements over time, such as sex, age (time-varying variable), educational level (time-varying variable), union duration (time-varying variable), time elapsed since arrival in Ouagadougou (time-varying variable), presence of children under 18 years old (time-varying variable), place of origin, type of

\footnotetext{
${ }^{5}$ We do not distinguish between children from previous and current unions. Children from previous unions are taken into account if they are the migrant's children (there are too few of them to distinguish them from the couple's children).

${ }^{6}$ The documentation on the missing data strategy is available upon request.

${ }^{7}$ It corresponded to 14 cases out of the 39. The assumption may be strong, but it is coherent with what our qualitative data reveal. We recommend that researchers planning a similar survey in the future include a question about the order of events: "Who arrived in Ouagadougou first: you or your partner?"
} 
neighbourhood in Ouagadougou, housing situation (time-varying variable), standard of living (time-varying variable), and household status, informing on whether the migrant is the household head ${ }^{8}$ (time-varying variable).

Table 1 describes the situation of migrants part of at least one union in 2015. Our sample includes more women than men (78\% of migrants in a union are women), which is not only due to the fact that women migrants are more likely to be in a union than single but also because most of the men present migrated to this part of the city before 2008, when the area was being rapidly populated with migrants as the city expanded (Flahaux \& Millogo, 2016). The surveyed population is relatively young (with $23 \%$ aged between 15 and 24 years old, $50 \%$ between 25 and 34 years, and $27 \% 35$ years or more), has a low educational level (60\% of migrants have never been to school and only $15 \%$ have reached secondary level or higher), and mainly comes from rural areas in Burkina Faso (74\%, against 13\% from urban areas and $14 \%$ from Côte d'Ivoire). Of the migrants, $14 \%$ do not have children, ${ }^{9} 54 \%$ have all their children in Ouagadougou, $11 \%$ have children living outside the city, and $21 \%$ have children both in and outside the city. As Table 1 also indicates, most of migrants live in informal neighbourhoods, own a house, and are not household heads. Only $5 \%$ of migrants live in households with a high standard of living. ${ }^{10}$

\section{- TABLE 1 HERE -}

Our sample includes 272 couple reunifications and 61 physical separations. The population "at risk" or likely to experience one of these events is not the same in both situations. Migrants in a union ${ }^{11}$ with the partner living outside Ouagadougou are taken into consideration for the analysis of couple reunification, while migrants in a union living with their partner in Ouagadougou (whether they arrived there alone or came to join their partner) are considered for the analysis of physical separation. Even though the longitudinal nature of our data is useful, one limitation of our study is that we have not collected data on the characteristics of the partner (except sex and union duration) or where that partner lives if not in Ouagadougou. However, other information can also be important as other factors may influence the family strategies and arrangements of couples (Nappa, 2017).

\section{- Qualitative data}

In order to better understand the processes leading to a decision to reunify the family or live separately as well as to gather information on the migrants' subjective point of view about their family and residential arrangements, 55 in-depth interviews with migrants in a union were carried out in the five formal and informal neighbourhoods included in the Ouaga HDSS. An initial sample was taken from among the migrants surveyed in the seventh round

\footnotetext{
${ }^{8}$ A household's members recognise one of their own as head of household, regardless of gender. The household head needs to be physically resident at the address. If $\mathrm{s} /$ he is absent for more than six months or dead, s/he is replaced by another household head determined by the members of the household.

${ }^{9}$ Only children under 18 years old are taken into account, as we wanted to study the presence of dependent children.

${ }^{10}$ The variable on standard of living was computed based on several household assets: the presence of a refrigerator and a television in the household, as well as the most expensive mode of transport in use in the household. For more detail, see Soura, Pison, Senderowicz, and Rossier (2013).

${ }^{11}$ In 2015 , only $1.79 \%$ of the surveyed migrants were polygamous (due to their relatively young age). As this is a very low proportion, in these cases we decided to consider only the union with the first wife.
} 
of the HDSS based on characteristics including type of neighbourhood, sex, and family trajectory (the couple's situation at the time of arrival in Ouagadougou and at the time of the seventh round). However, at the time of the following (eighth) round, as migrants are highly mobile and often not available during the day, many respondents could not be found, and so interviewers also had to engage in snowball sampling. Pilot interviews were carried out by the researchers at the stage of questionnaire development, and the qualitative survey was then carried out by a team of three Burkinabe interviewers, after being given two days of training by the research team.

We ended the qualitative data collection when saturation was reached, and our qualitative and quantitative samples match to some extent: out of 55 respondents in our qualitative data, we interviewed 32 women and 23 men, 14 of them living in a formal neighbourhood and 41 in an informal one; 34 of the respondents had migrated from a rural area in Burkina Faso, 13 from an urban area, and 8 from abroad (Côte d'Ivoire). We paid particular attention to the diversity of family and migration trajectories in order to ensure that a variety of experiences were reflected in the sample in terms of family arrangements where at least one of the partners migrated to Ouagadougou. This is shown in Table 2.

- TABLE 2 HERE -

\section{- Methods}

Firstly, we carry out quantitative descriptive analyses, describing the residential situation of migrant couples in Ouagadougou in 2015 and using Kaplan-Meier estimates to determine the extent of the occurrence of the events of couple reunification and physical separation.

Secondly, the qualitative interviews are subjected to thematic analyses in order to examine the migrants' general perceptions of living apart or together and the reasons behind their family decisions and arrangements: under which conditions do migrants live with their partner in Ouagadougou or not? How is the decision taken to reunify with the partner? And conversely, when the partner leaves, how is the decision taken to live physically separate? Hypotheses are then formulated based on the results of these analyses.

Quantitative analyses are then implemented in order to test the hypotheses. As a first step, a simple logistic regression is carried out to reveal the determinants of living together for couples in 2015. This is a transversal analysis highlighting the factors influencing the fact that some migrants live together with their partner in Ouagadougou while others do not. As a second step, we perform discrete-time event history analyses to study what drives a couple's reunification in Ouagadougou and a couple's physical separation when the migrant's partner leaves the city. These topics require analyses in terms of time: in the case of reunification, time elapsed since the beginning of the union or the arrival in Ouagadougou of one of the partners on their own, and in the case of physical separation, the time the couple spent living together in Ouagadougou, regardless of where the partner is from and where the union started. The analyses take into account the fact that, along with migrants who have reunified with their partner or have seen their partner leave the city, some have never experienced these events. The explanatory variables were measured over the entire duration. These could be fixed (such as sex or place of origin) or time-varying (such as age, union duration, or configuration of children). To ensure that the explanatory variables reflected the migrants' situation during the exposure period and not after experiencing the event, the events of couple reunification and physical separation were 
measured in the year $(t-1)$, which preceded the event in year $t$. For each of the regressions, we are particularly interested in the role of gender, configuration of children, union duration, housing situation, household standard of living, and type of neighbourhood. We control for age, educational level, place of origin, time elapsed since arrival in Ouagadougou, and household status (plus any previous reunification, in the case of physical separation).

\section{Quantifying the phenomenon of "living apart together"}

Descriptive analyses reveal that $25 \%$ of migrants in union living in Ouagadougou in 2015 have a partner who has not migrated to the capital city. As Figure 1 shows, there are more men (39\%) than women (21\%) in Ouagadougou who live apart from their partner. This first quantitative result already reveals that the case of individuals living without their partner in the capital city does not affect only men, as 1 out of 5 women in a union lives there without her partner.

Figure 1. Couple configuration for migrants in Ouagadougou, by sex of the migrants in Ouagadougou (\%) (weighted result)

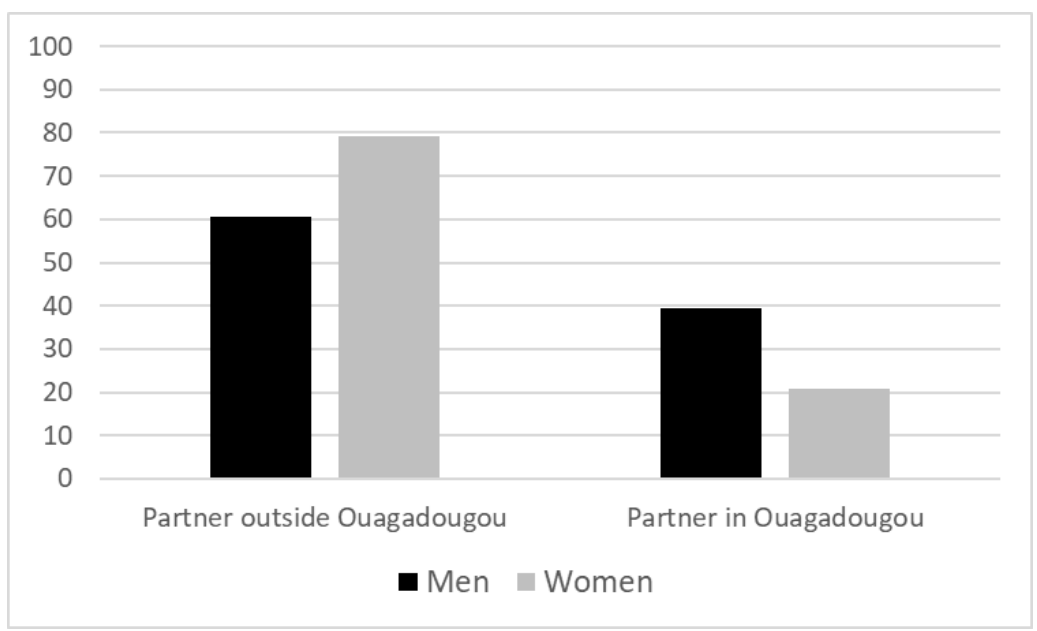

Data sources: Survey on the family histories of migrants (2015) and Ouaga HDSS

For migrants who arrived without their partner in Ouagadougou, the data allow us to determine the extent of the phenomenon and time elapsed before being joined by the partner in the city. Figure 2 shows that only 3 migrants out of 10 were joined by their partner after 8 years in Ouagadougou. This figure also shows that couple reunification, when it occurs, happens in the first years after the migrant's arrival in Ouagadougou. 
Figure 2. Proportion of migrants who are not joined by their partner in Ouagadougou, by time (in years) elapsed since initial arrival (Kaplan-Meier estimates) (weighted result)

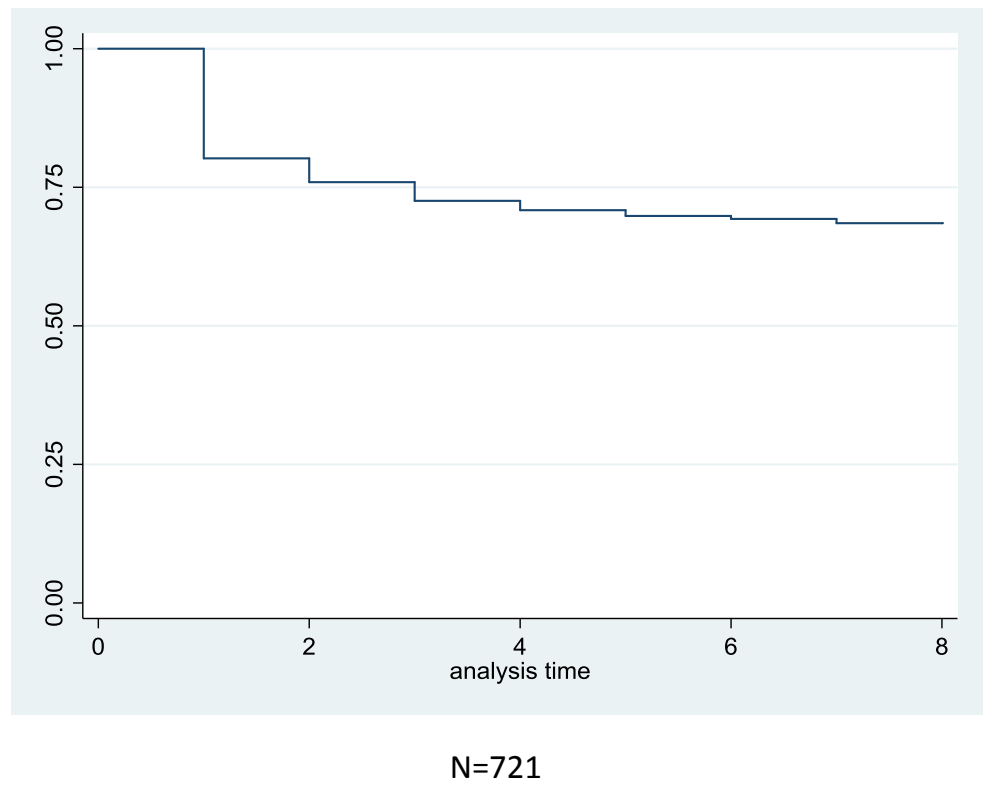

Data sources: Survey on the family histories of migrants (2015) and Ouaga HDSS

Note: $Y$-axis = proportion of migrants who are not joined by their partner in Ouagadougou; $\mathrm{x}$-axis = years elapsed between the arrival of the migrants in a union in Ouagadougou and reunification with their partner

As Figure 3 shows, the physical separation of couples is not a common phenomenon among migrants in a union living together in Ouagadougou: in 8 years fewer than 1 migrant in 10 sees his/her partner leave the city while he/her remains there. Physical separation is rare in the first two years of cohabitation in the city.

Figure 3. Proportion of migrants living together with their partner in Ouagadougou, according to time elapsed (in years) since the formation of the union or its reunification in the city (Kaplan-Meier estimates) (weighted result)

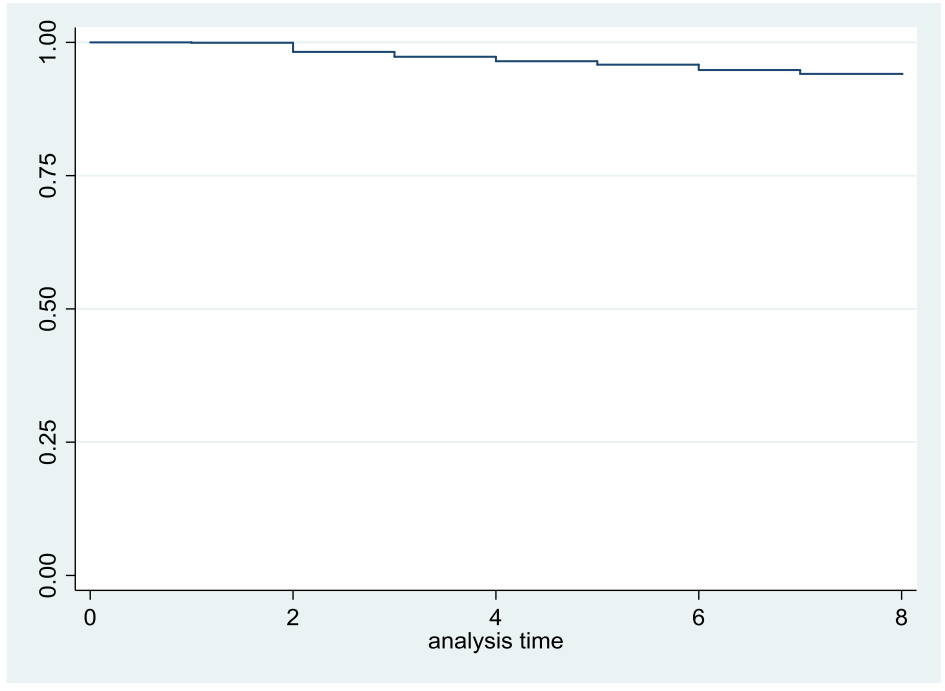

$N=1487$

Data sources: Survey on the family histories of migrants (2015) and Ouaga HDSS 
Note: $Y$-axis = proportion of migrants living together with their partner in Ouagadougou; $x$-axis = years elapsed between the beginning of the life together in Ouagadougou and the event of the partner's departure from

Ouagadougou

\section{Living together or at a distance: Insights from the qualitative analyses}

The qualitative interviews allow us to know the migrants' perceptions regarding living together, or not, as a couple. When the question "Do you think that it is important for people in a union to live together in the same house?" was asked, all the interviewees answered that it was indeed very important; they highlighted that married people "had to" live together. Living together was seen as an obligation for couples, and interestingly, even by those who had a partner who did not live in Ouagadougou. Respondents justified the importance of living together in personal, practical, economic, and social terms. First, respondents invoked personal reasons in explaining that living together "allows problems to be avoided between partners" as it "strengthens love" and allows for "having a normal life". Second, practical reasons were mentioned: not only is living together convenient for the sharing of tasks ("so that the man does not have to cook") and helping one another, it is also important in that it allows the couple "to have children" and "to raise children in a good way". Third, respondents sometimes expressed economic concerns in terms of the transportation costs involved in visiting the family outside Ouagadougou and considered that "living apart is costly". Fourth, some individuals declared social reasons for living together: for them, it is important "for the dignity of the family".

Several questions were then asked about the circumstances leading to living apart for migrants who had (or had had) a partner outside Ouagadougou, and for those currently living together with their partner in the city, what might push them to physically separate. The most common reason given was economic: migrants explained that they could not invite their partner (and family) to join them in Ouagadougou if their income was not sufficient to support everyone in the city. Many men explained that they had to live apart from their wife and children because they do not have their own house yet, or because they face financial difficulties. This was the case of Martin, who left his wife in the village to migrate to Ouagadougou. He explained: "The Mossis [Burkina Faso's main ethnic group] say: 'As long as the lion is not in a good bush, he will not be able to lead a good life'. If you do not have a good situation here, if you cannot afford to support your wife and children, you will have problems. (...) If you do not have a strong basis in Ouaga, do not bring your wife and children, otherwise you will argue with each other". Professional reasons were also given for couple living separately, such as when one of the partners is a civil servant sent to work outside Ouagadougou, or (particularly the case with the men) is presented with an opportunity to work elsewhere. The education of children was also often cited by women to justify their husband working outside of Ouagadougou and sending remittances in order to pay for the children's schooling (who remain in the city with their mother). For example, Emma's husband worked in Côte d'Ivoire while she stayed with the children in Ouagadougou. She explained: "I came to Ouaga with the children to take care of them, and he remained there to work and to help pay the fees for the children's education so that they will succeed in life and help us later". However, she also mentioned that she is getting old and her husband too, and therefore they are not constrained to live together anymore. This suggests that there is more social freedom for people who have been in a union for a long 
time and already have children to live apart. Finally, other social reasons also explained couples having to live apart: in some cases, the husband did not ask his wife to come to Ouagadougou or sent her back to the village because his ageing mother needs his daughterin-law to take care of her. In other cases, matrimonial problems were behind partners not living together, even if they are still in a union, though in this case the decision often comes from the men. Some differences in men's and women's discourses reveal that living apart is, from the men's perspective, a strategy, while it is more "endured" by the women, who often let their husband decide when they will join him in the capital city, as also suggested by another result of the project on the family strategies of migrants (Wayack Pambè, 2017). Similarly, it does not seem unusual for women to see their husband leave the city while they stay there with the children. Whatever the circumstances may be, because the situation of partners living apart is not perceived as normal, in all the cases the interviewees highlighted that they see the separation of the couple as temporary, and that the partners will reunite as soon as possible.

This analysis of the qualitative interviews allows us to put forward research hypotheses regarding the factors affecting living together in the city, couple reunification after living at a distance, and the physical separation of a couple in the city. Table 3 summarises the types of factors, the hypotheses developed from the qualitative analyses described above, and the variables available in the quantitative data in order to test these hypotheses.

- TABLE 3 HERE -

\section{Living apart together, reunifying, and separating: A quantitative analysis of the factors}

Finally, quantitative data are used to study the factors influencing couples' strategies and arrangements. (a) Firstly, the situation of migrants in 2015 is examined (transversally), in order to study what determines the fact that some migrants live with their partner while others live in a separate locality from their partner. To that end, a simple logistic regression is carried out. (b) Secondly, discrete-time event history analyses are implemented to investigate the factors at play in the two following events: (i) couple reunification and (ii) the physical separation of a couple.

\section{a. Living together or apart together: A transversal analysis}

Regarding the determinants for living together (rather than physically separated) in 2015 (Table 4), bivariate analysis reveals that women are more likely than men to live with their partner in the capital city. However, when controlling for the other factors (especially for age), migrants' sex is not significant. The age variable actually interacts with the sex variable (revealing that, compared to young men, older women are less likely to live with their partner).

Our hypothesis regarding union duration is confirmed. Where the union began more than 6 years earlier, couples are more likely to live at a distance than where it began more recently (1-3 years ago). According to the qualitative interviews, it is more acceptable for couples to live apart after they have already built a family. However, when migrants do not have children, results show they are also more likely to be in a situation of living in a different locality from their partner compared with those with children who are all in Ouagadougou. This may indicate either that the absence of children may lead to physical separation 
(before an eventual end of union) or that the migrant in Ouagadougou is waiting for a better economic situation before reunifying with the partner and having children in the city. The longitudinal analyses will help disentangle and understand this result in the next section.

As expected, owning a house influences the residential arrangements of couples. Migrants who own a house in Ouagadougou are twice as likely to live with their partner. This result is in line with the qualitative interviews suggesting that owning a house is a good economic indicator of integration in the capital city, particularly for men, as many of those interviewed said that their wife is not in Ouagadougou with them because they do not have their own house. On the other hand, neither the household's standard of living nor the type of neighbourhood where the migrants live appear as significant determinants when controlling for all the factors. ${ }^{12}$

Besides these main factors of interest, the multivariate analysis interestingly shows that age is not significant (in contrast with union duration), that migrants with a primary educational level are more likely to live with their partner than those who have never been to school, and that the presence of all the couple's children under 18 years old in Ouagadougou goes along with the presence of both partners there. Neither the place of origin nor the time elapsed since arriving in Ouagadougou influence the fact of living together. Finally, when migrants are household heads, they are more likely to live apart from their partner. This unsurprisingly indicates that the partner who is in Ouagadougou while his/her partner is elsewhere is often a household head.

- TABLE 4 HERE -

\section{b. A longitudinal analysis of the residential arrangements of migrant couples}

The longitudinal nature of our data allows us to gain in-depth knowledge of the residential dynamics of migrant couples. In this section, we present the determinants of the events of (i) the reunification of a couple and (ii) the physical separation of a couple.

\section{(i) The factors in couple reunification in Ouagadougou (Table 5)}

As shown in Table 5, women migrants are more likely to be joined in Ouagadougou by their partner than men migrants. This result corresponds with our hypothesis and reflects some migrants' and families' trajectories highlighted in the qualitative interviews: when men are alone in the city their wife is in the place of origin, and this arrangement may last for a long time, while when women are alone in the city, their husband works elsewhere (after having secured a place in Ouagadougou for his family), but will come back more rapidly to join the family. In other words, the separation is more temporary when women are in Ouagadougou without their husband.

The results of the variables related to the familial cycle also confirm our hypothesis. Migrants who have been in a union for more than 3 years are less likely to reunify compared to those who started their union more recently. Migrants who have just started an union

\footnotetext{
${ }^{12}$ However, the bivariate analyses show that migrants in informal areas are less likely to live together with their partner, and those living in households with a mid-level standard of living have higher chances of living together.
} 
are likely to want to live together with their partner because they intend to have children, unlike longstanding couples, as explained previously by a migrant woman who said that she did not have to live with her husband anymore because they are not a "recently married couple". Along the same line, another quantitative result reveals that when the couple does not have children, the chances of reunification are as likely as when all the children are in Ouagadougou, which highlights the importance of living together when the couple aspires to having children.

Regarding the integration of migrants in the city, an important factor in couple reunification in Ouagadougou is the ownership of a house. When migrants own a house, their chances of being joined by a partner is higher compared to those who are hosted or rent a house in the city. This result also corresponds with our expectations from the qualitative interviews: it is important for migrants to have their own house in order to be able to bring their family to the city. This variable is much more important than the standard of living of the household, which is not a significant determinant in couple reunification. The multivariate quantitative results also indicate that migrants living in an informal neighbourhood are less likely to be joined by their partner, which could be related to the fact that these migrants are poorer. Our qualitative interviews with migrants living in formal and informal areas did not highlight a difference in terms of strategies in terms of residential arrangements for couples, but it is also possible that the lack of infrastructure and services in informal areas does not provide an incentive for migrants to bring their family members, who may have better living conditions outside Ouagadougou. At the household level, the standard of living does not influence couple reunification in Ouagadougou, but being the household head leads to better chances of reunifying with the partner in the household.

The other results of the regression show the insignificant role played by age, educational level, and place of origin, but confirm what the descriptive analysis on time elapsed since arrival in Ouagadougou indicated: the more time passes, the fewer reunifications there are. Finally, having all the children in Ouagadougou is an important determinant for couple reunification compared with the cases where there are children outside Ouagadougou. Many migrants insisted in the qualitative interviews on the fact that it is important for both parents to live together for the children's education. However, reunifying both the partner and the children in the city can be costly, and some migrants prefer to leave their partner behind with the children. The result may also point to cases of migration taking place in the context of diversification of resources, where only one parent-more likely the fathermigrates to Ouagadougou.

\section{- TABLE 5 HERE -}

\section{(ii) The factors in the physical separation of a couple (Table 6)}

Couples in a union may start to live apart for diverse reasons. Table 6 shows the factors at play in the physical separation of a couple for migrants in Ouagadougou. The results first indicate that women are much more likely to have their husband leave the city while they stay in Ouagadougou. This result confirms our hypothesis that men have higher chances of leaving their family in Ouagadougou to take up work elsewhere, where they may have better opportunities. Women are less likely to migrate out of Ouagadougou and leave their husband behind. In a context where most of the time men make the decisions related to 
their wife's mobility, it is nonetheless not so common for them to "send" back their wife to their place of origin. It also means, as reflected in the qualitative interviews, that women are less mobile after their migration to Ouagadougou - which can result from the man making the decision, a joint decision, or the woman's wish, but which does not prevent the women from visiting their family for short periods outside Ouagadougou. In addition, another study shows that most women migrants want to stay in Ouagadougou (Mallon, 2017).

The other results in the Table 6 show a certain heterogeneity in the situations of physical separations. Our hypothesis on the role of union duration is verified only by the bivariate results. When controlling for all factors, a union that has lasted for a long time does not lead to more physical separations. Interestingly, a previous physical separation (followed by a reunification) is likely to be followed by another separation. In a few qualitative interviews, men explained that they had to send their wife back to the village because they had to stay with their mother or because their economic situation in the city did not allow them to support themselves and their wife. Another example highlighted in the qualitative interviews is civil servants sent to work outside Ouagadougou for repeated temporary periods and leaving their family behind in the capital city when they do so. Our results also reveal that when the couple does not have children, it is not likely that one of the partners will leave Ouagadougou; the chances that they will stay in the capital city together are as high as those of couples who live there together with all their children. When all the children live outside the city, a physical separation is more likely, suggesting either that the migration of the children to the city was not planned from the start (for example, a respondent in our qualitative interviews explained how his partner who came to Ouagadougou due to a health problem and returned to the place of origin when she felt better) or that life as a family with the children in Ouagadougou would not be sustainable.

Our hypothesis related to integration into the city is not verified. When a migrant is from a rural area, the likelihood that their partner leaves the city is very weak compared to a migrant from another urban area within Burkina Faso. Couples living in informal areas also have low chances of starting to live apart. However, neither the ownership of a house nor standard of living play a role in couple separation, revealing that the physical separation of couples is associated with a heterogeneity of situations.

\section{- TABLE 6 HERE -}

\section{Conclusion}

In the context of urbanisation in West Africa, little had been known about the extent and the conditions under which migrants in a union live apart or together, are joined by their partner, or start to live in separate localities. This research has produced innovative findings. Focusing on the case of Ouagadougou and using a mixed-methods approach, it reveals that despite the "obligation" for couples to live together, living in different localities is perceived as possible in some circumstances and accounts for $25 \%$ of migrants in a union in 2015 . It shows that the residential arrangements of migrant couples are influenced by factors in three areas: integration into the city, family cycle, and gender relations.

First, as also highlighted in the international LAT literature (González-Ferrer 2011; Baizán et al., 2014; Ambrosini 2008), our results suggest that the non-reunification of couples in 
Ouagadougou is mostly due to economic factors. It mainly happens either when the husband-alone in Ouagadougou-does not own a house and cannot afford to support his wife in decent conditions if she lives with him in the city, or when the wife is alone with the children in the city because her husband works elsewhere in order to help support them, in particular to provide resources to pay for the education of the children in Ouagadougou. This somewhat conforms to the new economics of labour migration (NELM) highlighting the strategic interest in families remaining divided, with the specificity in our case that the couple wishes to be reunited in Ouagadougou (Mallon, 2017).

Second, for migrants in the city, couple reunification most frequently occurs in the years following the establishment of the union, indicating the importance of living together for young couples that want to start a family. The study of Caarls and Mazzucato (2016) on Ghanaian migration conversely reveals that reunification in Europe is conversely more likely to occur for partners who lived together for a long time prior to living apart. This suggests that it is comparatively harder for couples to be reunified where there are borders involved.

Third, conversely to a study on immigrants in Italy revealing that family reunification was more common when men migrated first (Barbiano di Belgiojoso \& Terzera, 2018), in our research focusing on a context of shorter-distance migration, women are more likely to be joined by their partner in the city than men. However, our analyses on the couple's physical separation show that men have higher chances of leaving the city to go to work elsewhere while the partner remains in Ouagadougou. Couples who have experienced reunification are more likely to live apart again, but we can conclude that most of the time the physical separation is temporary, as our results on the determinants of couple reunification have shown that women are likely to be joined by their partner in the city.

Our findings contribute to knowledge about migrant couples "living apart together", a phenomenon traditionally studied in the literature; yet this study also goes further thanks to the implementation of a longitudinal approach: it considers the residential dynamics of migrant couples rather than their situation at the time of data collection only. The longitudinal analysis of both couple reunification and physical separation shows that these phenomena are interconnected. Our research also shows that, beyond the importance of economic factors and the diversification of outcomes to explain the dispersion of families (Findley, 1997; Guilmoto \& Sandron, 2000), it is also important to consider the social logics at stake, as highlighted in previous research (Nappa, 2017; Baizán et al., 2014). The case of Burkinabe migration, in West Africa, complements the existing literature related to translocal families, mainly concerned with Eastern and Southern Africa (Amoateng \& Richter, 2017; Camlin et al., 2014; Hosegood et al., 2009), as the historical and social contexts between these regions are not similar. Our results nuance the common idea that, in the context of urbanisation, men always migrate first and women follow them later in order to stay together in the African capital city (Fargues, 1989). Instead, policy makers should take into account the fact that, even if migrants aspire to live together with their family in the cities, many of them must live at a distance from their partner for a long time and have to develop strategies in order to maintain ties with their family and provide for their needs. Since these migrants often live in a precarious and informal environment in the periphery of the cities (Flahaux \& Bakewell, 2017), it should be a priority of urban policies to focus on improving the structures and living conditions in these areas. A better understanding of family and migration dynamics is crucial for the development of appropriate urban policies. 
While this research implements an original approach and reveals innovative findings, it also presents some limitations. On the one hand, the quantitative data did not allow us to take into account the migrants' professional situation and, more broadly, his/her partner's situation. This last element would have been very important as characteristics of the individual and of his/her place of residence outside Ouagadougou may play an essential role in the couples' residential and family arrangements (Nappa, 2017). Also, our quantitative survey did not collect information as to how often migrants living at a distance from their partner visit (or are visited by) him/her. The distance separating the partners living apart is also not available. On the other hand, respondents in the qualitative interviews were met only once by the interviewers, and those living apart from their partner may have simplified their justification of this arrangement, hiding some intimate realities. Strategies to overcome these limitations should be integrated into future research.

More in-depth research in line with our results would be needed to better understand couple reunification outside the city, the future of unions for partners who live for longer periods apart, and the relation between families and migration in other contexts of urbanisation. 


\section{References}

Amoateng, A. Y., Richter, L. M. (2007). Living arrangements in South Africa. In A. Y. Amoateng \& T. B. Heaton (Eds.), Families and households in post-apartheid South Africa: Socio-demographic perspectives (pp. 43-59). Cape Town: HSRC Press.

Ambrosini, M. (2008). Séparées et réunies : familles migrantes et liens transnationaux. Revue Européenne des Migrations Internationales, 24 (3), 79-106.

Baizán, P., Beauchemin, C., González-Ferrer, A. (2014). An origin and destination perspective on family reunification: The case of Senegalese couples. European Journal of Population, 30, 65-87. http://doi.org/10.1007/s10680-013-9305-6

Barou, J. (2001). La famille à distance : nouvelles stratégies familiales chez les immigrés d'Afrique sahélienne. Hommes et Migrations, 1232, 16-25. http://doi.org/10.3406/homig.2001.3715

Beauchemin, C., Nappa, J., Schoumaker, B., Baizan, P., González-Ferrer, A., Caarls, K., Mazzucato, V. (2015). Reunifying versus living apart together across borders: A comparative analysis of sub-Saharan migration to Europe. International Migration Review, 49 (1), 173199. http://doi.org/10.1111/imre.12155

Bennett, R., Hosegood, V., Newell, M.-L., McGrath, N. (2015). An approach to measuring dispersed families with a particular focus on children 'left behind' by migrant parents: Findings from rural South Africa. Population, Space and Place, 21, 322-334. http://doi.org/10.1002/psp.1843

Bledsoe, C. H., Sow, P. (2011). Family reunification ideals and the practice of transnational reproductive life among Africans in Europe. In C. Browner, \& C. Sargent (Eds.), Reproduction, Globalism, and the State (pp. 175-191), Durham, NC: Duke University Press.

Blion, R. (1992). Retour au pays des Burkinabé de Côte-d'Ivoire. Hommes et Migrations, 1160, 28-31. http://doi.org/10.3406/homig.1992.1931

Boyer, F. (2010). Croissance urbaine, statut migratoire et choix résidentiels des Ouagalais : vers une insertion urbaine ségrégée ?, Revue Tiers Monde, 201, 47-64. http://doi.org/10.3917/rtm.201.0047

Bredeloup, S. (2006). Réinstallation à Ouagadougou des "rapatriés " burkinabè de Côte d'Ivoire. Afrique Contemporaine, 217, 185-201. http://doi.org/10.3917/afco.217.0185

Caarls, K., de Valk, H. (2017). Relationship trajectories, living arrangements, and international migration among Ghanaians. Population, Space and Place, 23, e2046. https://doi.org/10.1002/psp.2046

Caarls, K., Mazzucato, V. (2016). Transnational relationships and reunification: Ghanaian couples between Ghana and Europe. Demographic Research, 34 (21), 587-614.

Caarls, K., Haagsman, K., Kraus, E., Mazzucato, V. (2018). African transnational families: Cross-country and gendered comparisons. Population, Space and Place, 24 (7), e2162. https://doi.org/10.1002/psp.2162 
Camlin, C., Snow, R., Hosegood, V. (2014). Gendered Patterns of Migration in Rural South Africa. Population, Space and Place, 20, 528-551. https://doi.org/10.1002/psp.1794

Comhaire-Sylvain, S. (1968). Femmes de Kinshasa hier et aujourd'hui. The Hague : Mouton, $384 \mathrm{p}$.

Delaunay, D., Boyer, F. (2017a). Habiter Ouagadougou. Monographies Sud-Nord, 5, 84 pp. Paris: IEDES, Université Paris 1 Panthéon Sorbonne. Retrieved from: http://iedespubli.hypotheses.org/986

Delaunay, D., Boyer, F. (2017b). Capital social, migration et développement, Ouagadougou (Burkina Faso). Monographies Sud-Nord, 1, 88 pp. Paris: IEDES, Université Paris 1 Panthéon Sorbonne. Retrieved from: http://iedespubli.hypotheses.org/907

Fargues, P. (1989). Déficit vivrier et structures familiales en Afrique au Sud du Sahara. Population (French Edition), 44, 631-648. http://doi.org/10.2307/1533422

Findley, S. (1997). Migration and family interactions in Africa. In A. Adepoju (Ed.), Family, Population \& Development in Africa (pp. 109-138). London: Zed Books.

Flahaux, M.-L., Bakewell, O. (2017). Les stratégies familiales des migrants à Ouagadougou. Final report, Global Programme Migration and Development, Swiss Agency for Development and Cooperation, International Migration Institute, University of Oxford, 31p.

Flahaux, M.-L., Millogo, R. (2016). Premiers résultats sur les migrations à Ouagadougou. Workshop organised as part of the project "Family Strategies of Migrants in Ouagadougou", Ouagadougou, Burkina Faso.

González-Ferrer, A. (2011). Spousal reunification among recent immigrants in Spain: Links with undocumented migration and the labour market. In A. Kraler, E. Kofman, M. Kohli, \& C. Schmoll (Eds.), Gender, generations and the family in international migration (pp. 193-218). Amsterdam: Amsterdam University Press.

Gregory, J. W., Cordell, D. D., Piché, V. (1989). La mobilisation de la main-d'oeuvre burkinabé, 1900-1974: Une vision retrospective. Canadian Journal of African Studies, 23 (1), 73-105. http://doi.org/10.1080/00083968.1989.10804245

Guilmoto, Z. C., Sandron, F. (2000). La dynamique interne des réseaux migratoires dans les pays en développement. Population (French Edition), 55, 105-135. http://doi.org/10.2307/1534767

Hosegood, V., McGrath, N., Moultrie, T. (2009). Dispensing with marriage: Marital and partnership trends in rural KwaZulu-Natal, South Africa 2000-2006. Demographic Research, 20, 279-312. http://doi.org/10.4054/DemRes.2009.20.13

Kwena, Z. A., Camlin, C. S., Shisanya, C. A., Mwanzo, I., Bukusi, E. A. (2013). Short-Term Mobility and the Risk of HIV Infection among Married Couples in the Fishing Communities along Lake Victoria, Kenya. PLoS ONE 8 (1), e54523. https://doi.org/10.1371/journal.pone.0054523

Lurie, M. N. (2006). The Epidemiology of Migration and HIV/AIDS in South Africa. Journal of Ethnic and Migration Studies, 32 (4), 649--666. https://doi.org/10.1080/13691830600610056 
Lututala, M. (1987). Dynamique des migrations au Zaïre : le réseau de Kinshasa (PhD thesis). Demography, Université de Montréal, Montréal, Canada.

Mallon, C. (2017). The aspirations of migrants in an African capital: Understanding their wish to stay or go (Master's dissertation, 88 pp.). University of Grenoble, Grenoble, France.

Mazzucato, V., Schans, D., Caarls, K., Beauchemin, C. (2015). Transnational families between Africa and Europe. International Migration Review, 49, 142-172. http://doi.org/10.1111/imre.12153

Nappa, J. (2017). La formation et le devenir des couples congolais dans le contexte de la migration internationale ( $\mathrm{PhD}$ thesis). Social and Political Sciences, Université catholique de Louvain, Louvain-la-Neuve, Belgium.

Néya, S. (2016a). Quand les transferts financiers contribuent à la structuration de la famille transnationale dans l'espace migratoire ivoiro-burkinabè. In S. Bredeloup \& M. Zongo (Eds.), Repenser les mobilités burkinabè (pp. 175-198). Paris: L’Harmattan.

Néya, S. (2016b). Les mobilités spatiales féminines entre logiques individuelle et familiale : l'exemple des migrantes burkinabè entre le Burkina Faso et la Côte d'Ivoire. EchoGéo, 37, 19 pp. Retrieved from: http://journals.openedition.org/echogeo/14675. http://doi.org/10.4000/echogeo.14675

Ouedraogo, D. (1993). Les migrations burkinabè sous la révolution démocratique et populaire : continuité ou rupture ? In D. Cordell, D. Gauvreau, R. Gervais, \& C. Le Bourdais (Eds.), Population, reproduction, sociétés : perspectives et enjeux de démographie sociale (pp. 329-350). Montréal: Presses de l’Université de Montréal.

Pilon, M., Vignikin, K. (2006). Ménages et familles en Afrique subsaharienne. Paris: Éditions des archives contemporaines.

Quiminal, C. (1995). La famille soninké en France. Hommes \& Migrations, 1185, 26-31.

Raghunathan, T. E. (2004). What do we do with missing data? Some options for analysis of incomplete data. Annual Review of Public Health, 25, 99-117. https://doi.org/10.1146/annurev.publhealth.25.102802.124410

Rossier, C., Soura, A., Baya, B., Compaoré, G., Dabiré, B., Dos Santos, S., ... Zourkaleini, Y. (2012). Profile: The Ouagadougou Health and Demographic Surveillance System. International Journal of Epidemiology, 41, 658-666. http://doi.org/10.1093/ije/dys090

Soura, A. (2014). Dynamique démographique des quartiers informels de Ouagadougou : éclairage à partir des données d'un observatoire de population. Revue de géographie du LARDYMES, 13, 133-146.

Soura, A., Pison, G., Senderowicz, L., Rossier, C. (2013). Religious differences in child vaccination rates in urban Africa: Comparison of population surveillance data from Ouagadougou, Burkina Faso. African Population Studies 27(2): 174-187. http://doi.org/10.11564/27-2-439

Toyota, M., Yeoh, B., Nguyen, L. (2007). Editorial introduction: bringing the 'left behind' back into view in Asia: A framework for understanding the 'migration-left behind nexus'. Population, Space and Place, 13, 157-161. http://doi.org/10.1002/psp.433 
United Nations, Department of Economic and Social Affairs, Population Division (2014). World Urbanization Prospects: The 2014 Revision, CD-ROM Edition.

Vissers, D. C., Voeten, H. A., Urassa, M., Isingo, R., Ndege, M., Kumogola, Y., Mwaluko, G., Zaba, B., de Vlas, S. J., Habbema, J. D. (2008). Separation of Spouses Due to Travel and Living Apart Raises HIV Risk in Tanzanian Couples. Sexually Transmitted Diseases, 35 (8), 714-20. https://doi.org/10.1097/OLQ.0b013e3181723d93

Wayack Pambè, M. (2017, September 5). Migrer à Ouagadougou : un facteur d'autonomisation pour les femmes ? Presentation presented at the workshop "Family Strategies of Migrants," University of Ouagadougou, Ouagadougou, Burkina Faso.

Zamwangana, T. (2005). Migration féminine et fécondité à Kinshasa. Louvain-la-Neuve : Académia, 305p.

Zongo, M. (2003). La diaspora burkinabè en Côte d'Ivoire : Trajectoire historique, recomposition des dynamiques migratoires et rapport avec le pays d'origine. Politique africaine, 90 (2), 113-126. http://doi.org/10.3917/polaf.090.0113 
Table 1. Description of the sample of migrants in a union in 2015 (\%) (weighted results)

\begin{tabular}{|c|c|c|}
\hline Variables & Modalities & $\%$ \\
\hline \multirow[t]{2}{*}{ Sex } & Men & 22 \\
\hline & Women & 78 \\
\hline \multirow[t]{4}{*}{ Age } & $15-24$ years & 23 \\
\hline & $25-34$ years & 50 \\
\hline & $35-44$ years & 17 \\
\hline & 45 years or more & 10 \\
\hline \multirow[t]{3}{*}{ Educational level } & None & 60 \\
\hline & Primary & 21 \\
\hline & Secondary or tertiary & 15 \\
\hline \multirow[t]{4}{*}{ Union duration } & $1-3$ years & 15 \\
\hline & $4-6$ years & 30 \\
\hline & $7-12$ years & 32 \\
\hline & 13 years or more & 23 \\
\hline \multirow[t]{4}{*}{ Children under 18 years old } & All in Ouagadougou & 54 \\
\hline & All outside Ouagadougou & 11 \\
\hline & $\begin{array}{l}\text { Some in and some outside } \\
\text { Ouagadougou }\end{array}$ & 21 \\
\hline & No children & 14 \\
\hline \multirow[t]{3}{*}{ Place of origin } & Urban area in Burkina Faso & 13 \\
\hline & Rural area in Burkina Faso & 74 \\
\hline & Abroad & 13 \\
\hline \multirow{3}{*}{$\begin{array}{l}\text { Time elapsed since arrival in } \\
\text { Ouagadougou }\end{array}$} & $1-2$ years & 2 \\
\hline & $3-5$ years & 36 \\
\hline & 6 years and more & 62 \\
\hline \multirow[t]{2}{*}{ Type of neighbourhood } & Formal & 24 \\
\hline & Informal & 76 \\
\hline \multirow[t]{2}{*}{ House owner } & Yes & 79 \\
\hline & No & 21 \\
\hline \multirow[t]{3}{*}{ Standard of living } & Poor & 25 \\
\hline & Middle & 69 \\
\hline & High & 5 \\
\hline \multirow[t]{2}{*}{ Household head } & Yes & 25 \\
\hline & No & 75 \\
\hline $\mathrm{N}$ & 1896 & \\
\hline
\end{tabular}


Table 2. Family experiences and situations of the 55 migrants who participated in the qualitative interviews

\begin{tabular}{|c|c|c|c|c|}
\hline & & Men & Women & Total \\
\hline \multirow{4}{*}{$\begin{array}{l}\text { Migrants living in } \\
\text { Ouagadougou } \\
\text { together with their } \\
\text { partner }\end{array}$} & $\begin{array}{l}\text { Migrants who joined } \\
\text { their partner }\end{array}$ & 2 & 11 & 13 \\
\hline & $\begin{array}{l}\text { Migrants who } \\
\text { brought in their } \\
\text { partner }\end{array}$ & 6 & 2 & 8 \\
\hline & $\begin{array}{l}\text { Migrants who } \\
\text { arrived together with } \\
\text { their partner }\end{array}$ & 1 & 1 & 2 \\
\hline & $\begin{array}{l}\text { Migrants who began } \\
\text { their union in } \\
\text { Ouagadougou }\end{array}$ & 6 & 9 & 15 \\
\hline \multirow[t]{2}{*}{$\begin{array}{l}\text { Migrants living in } \\
\text { Ouagadougou apart } \\
\text { from their partner }\end{array}$} & $\begin{array}{l}\text { Migrant's partner } \\
\text { has never lived in } \\
\text { Ouagadougou }\end{array}$ & 6 & 7 & 13 \\
\hline & $\begin{array}{l}\text { Migrant's partner } \\
\text { has left } \\
\text { Ouagadougou }\end{array}$ & 2 & 2 & 4 \\
\hline Total & & 23 & 32 & 55 \\
\hline
\end{tabular}


Table 3. Research hypotheses related to factors and indicators associated with living together, couple reunification, and couples' physical separation

\begin{tabular}{|l|l|l|}
\hline Type of factor & Hypotheses & Main variables of interest \\
\hline Gender relations & $\begin{array}{l}\text { Since men seem to have the decision-making power } \\
\text { within the couple and seem to be more mobile than } \\
\text { women, women would be more likely to be joined } \\
\text { by their partner in Ouagadougou, and men, when } \\
\text { they live there with their wife, would be more likely } \\
\text { to leave the city. }\end{array}$ & \\
\hline Family cycle & $\begin{array}{l}\text { Migrants would be more likely to live with their } \\
\text { partner if their union was recently formed. } \\
\text { Therefore, there would be more couple } \\
\text { reunifications and fewer physical separations among } \\
\text { migrants in the years immediately following the } \\
\text { beginning of union. }\end{array}$ & \\
\hline $\begin{array}{l}\text { Integration into the } \\
\text { city }\end{array}$ & $\begin{array}{l}\text { As good integration into the capital city seems to go } \\
\text { along with living together, migrants owning a house } \\
\text { and living in wealthy households and in formal } \\
\text { neighbourhoods would be more likely to live or } \\
\text { reunify with their partner, and less likely to } \\
\text { experience physical separation from their partner. } \\
\text { On the contrary, migrants who do not own a house } \\
\text { and who live in poor households and in informal } \\
\text { neighbourhoods would be less likely to live together } \\
\text { with their partner or to bring him/her to the city, } \\
\text { and more likely to see their partner leaving them } \\
\text { behind in the city. }\end{array}$ & $\begin{array}{l}\text { - Household standard of } \\
\text { living }\end{array}$ \\
- Type of neighbourhood \\
\hline
\end{tabular}


Table 4. Determinants of migrants in a union living together with their partner in Ouagadougou in 2015 (logistic regression) (weighted results)

\begin{tabular}{|c|c|c|c|}
\hline \multirow[t]{2}{*}{ Variables } & \multirow[t]{2}{*}{ Modalities } & \multicolumn{2}{|c|}{ Odd ratios } \\
\hline & & Gross effect & Net effect \\
\hline \multirow[t]{2}{*}{ Sex } & Men & 1 & 1 \\
\hline & Women & $\begin{array}{l}2.416^{* * *} \\
(0.289)\end{array}$ & $\begin{array}{l}1.479 \\
(0.375) \\
\end{array}$ \\
\hline \multirow[t]{4}{*}{ Age } & $15-24$ years & 1 & 1 \\
\hline & $25-34$ years & $\begin{array}{l}0.269 * * * \\
(0.053)\end{array}$ & $\begin{array}{l}0.763 \\
(0.189) \\
\end{array}$ \\
\hline & $35-44$ years & $\begin{array}{l}0.100 * * * \\
(0.021) \\
\end{array}$ & $\begin{array}{l}0.807 \\
(0.232) \\
\end{array}$ \\
\hline & 45 years or more & $\begin{array}{l}0.046 * * * \\
(0.011) \\
\end{array}$ & $\begin{array}{l}0.598 \\
(0.208) \\
\end{array}$ \\
\hline \multirow[t]{3}{*}{ Educational level } & None & 1 & 1 \\
\hline & Primary & $\begin{array}{l}1.705^{* * *} \\
(0.240)\end{array}$ & $\begin{array}{l}1.581 * * * \\
(0.273)\end{array}$ \\
\hline & Secondary or tertiary & $\begin{array}{l}1.801 * * * \\
(0.295) \\
\end{array}$ & $\begin{array}{l}1.247 \\
(0.274) \\
\end{array}$ \\
\hline \multirow[t]{4}{*}{ Union duration } & $1-3$ years & 1 & 1 \\
\hline & $4-6$ years & $\begin{array}{l}0.929 \\
(0.245) \\
\end{array}$ & $\begin{array}{l}0.875 \\
(0.265) \\
\end{array}$ \\
\hline & $7-12$ years & $\begin{array}{l}0.237^{* * *} \\
(0.056) \\
\end{array}$ & $\begin{array}{l}0.282 * * * \\
(0.081) \\
\end{array}$ \\
\hline & 13 years or more & $\begin{array}{l}0.069 * * * \\
(0.016)\end{array}$ & $\begin{array}{l}0.146 * * * \\
(0.045)\end{array}$ \\
\hline \multirow{4}{*}{$\begin{array}{l}\text { Children under } 18 \\
\text { years old }\end{array}$} & All in Ouagadougou & 1 & 1 \\
\hline & All outside Ouagadougou & $\begin{array}{l}0.063^{* * *} \\
(0.012) \\
\end{array}$ & $\begin{array}{l}0.099 * * * \\
(0.021) \\
\end{array}$ \\
\hline & $\begin{array}{l}\text { Some in and some outside } \\
\text { Ouagadougou }\end{array}$ & $\begin{array}{l}0.089 * * * \\
(0.014)\end{array}$ & $\begin{array}{l}0.172 * * * \\
(0.030)\end{array}$ \\
\hline & No children & $\begin{array}{l}0.198^{* * *} \\
(0.035)\end{array}$ & $\begin{array}{l}0.204 * * * \\
(0.043)\end{array}$ \\
\hline \multirow[t]{3}{*}{ Place of origin } & Urban area in Burkina Faso & 1 & 1 \\
\hline & Rural area in Burkina Faso & $\begin{array}{l}1.165 \\
(0.180) \\
\end{array}$ & $\begin{array}{l}1.114 \\
(0.223) \\
\end{array}$ \\
\hline & Abroad & $\begin{array}{l}0.912 \\
(0.185) \\
\end{array}$ & $\begin{array}{l}1.107 \\
(0.283) \\
\end{array}$ \\
\hline \multirow{3}{*}{$\begin{array}{l}\text { Time elapsed since } \\
\text { arrival in Ouagadougou }\end{array}$} & $1-2$ years & 1 & 1 \\
\hline & $3-5$ years & $\begin{array}{l}0.283^{*} \\
(0.210) \\
\end{array}$ & $\begin{array}{l}0.920 \\
(0.668) \\
\end{array}$ \\
\hline & 6 years or more & $\begin{array}{l}0.242^{* *} \\
(0.179) \\
\end{array}$ & $\begin{array}{l}1.062 \\
(0.769) \\
\end{array}$ \\
\hline \multirow[t]{2}{*}{ Type of neighbourhood } & Formal & 1 & 1 \\
\hline & Informal & $\begin{array}{l}0.755^{* *} \\
(0.102) \\
\end{array}$ & $\begin{array}{l}0.752 \\
(0.144) \\
\end{array}$ \\
\hline \multirow[t]{2}{*}{ House owner } & Yes & 1 & 1 \\
\hline & No & $\begin{array}{l}0.546 * * * \\
(0.068) \\
\end{array}$ & $\begin{array}{l}0.497 * * * \\
(0.084) \\
\end{array}$ \\
\hline \multirow[t]{3}{*}{ Standard of living } & Poor & 1 & 1 \\
\hline & Middle & $\begin{array}{l}1.330 * * \\
(0.161) \\
\end{array}$ & $\begin{array}{l}0.978 \\
(0.151) \\
\end{array}$ \\
\hline & High & $\begin{array}{l}1.188 \\
(0.307)\end{array}$ & $\begin{array}{l}0.657 \\
(0.268)\end{array}$ \\
\hline \multirow[t]{2}{*}{ Household head } & Yes & 1 & 1 \\
\hline & No & $\begin{array}{l}3.102 * * * \\
(0.361)\end{array}$ & $\begin{array}{l}1.594 * \\
(0.379)\end{array}$ \\
\hline
\end{tabular}




\begin{tabular}{|l|l|l|}
\hline Constant term & & $\begin{array}{l}21.815^{* * *} \\
(17.599)\end{array}$ \\
\hline $\mathrm{N}=1801$ \\
\hline Standard errors in parentheses. ${ }^{*} \mathrm{p}<0.10,{ }^{* *} \mathrm{p}<0.05,{ }^{* * *} \mathrm{p}<0.01$ \\
\hline \multicolumn{2}{|l|}{ Data sources: Survey on the family histories of migrants (2015) and Ouaga HDSS } \\
\hline
\end{tabular}


Table 5. Determinants of couple reunification in Ouagadougou between 2008 and 2015 (discrete-time event history logistic regression) (weighted results)

\begin{tabular}{|c|c|c|c|}
\hline \multirow[t]{2}{*}{ Variables } & \multirow[t]{2}{*}{ Modalities } & \multicolumn{2}{|c|}{ Odd ratios } \\
\hline & & Gross effect & Net effect \\
\hline \multirow[t]{2}{*}{ Sex } & Men & 1 & 1 \\
\hline & Women & $\begin{array}{l}1.199 \\
(0.189)\end{array}$ & $\begin{array}{l}2.044^{* *} \\
(0.705)\end{array}$ \\
\hline \multirow[t]{4}{*}{ Age } & $15-24$ years & 1 & 1 \\
\hline & $25-34$ years & $\begin{array}{l}0.574 * * * \\
(0.102)\end{array}$ & $\begin{array}{l}1.297 \\
(0.411)\end{array}$ \\
\hline & $35-44$ years & $\begin{array}{l}0.410 * * * \\
(0.089) \\
\end{array}$ & $\begin{array}{l}1.379 \\
(0.638) \\
\end{array}$ \\
\hline & 45 years or more & $\begin{array}{l}0.312^{* * *} \\
(0.077) \\
\end{array}$ & $\begin{array}{l}1.047 \\
(0.625)\end{array}$ \\
\hline \multirow[t]{3}{*}{ Educational level } & None & 1 & 1 \\
\hline & Primary & $\begin{array}{l}1.170 \\
(0.231)\end{array}$ & $\begin{array}{l}0.876 \\
(0.268)\end{array}$ \\
\hline & Secondary or tertiary & $\begin{array}{l}1.301 \\
(0.282)\end{array}$ & $\begin{array}{l}0.641 \\
(0.238) \\
\end{array}$ \\
\hline \multirow[t]{4}{*}{ Union duration } & $1-3$ years & 1 & 1 \\
\hline & $4-6$ years & $\begin{array}{l}0.314^{* * *} \\
(0.068)\end{array}$ & $\begin{array}{l}0.291 * * * \\
(0.088)\end{array}$ \\
\hline & $7-12$ years & $\begin{array}{l}0.218^{* * *} \\
(0.042) \\
\end{array}$ & $\begin{array}{l}0.177^{* * *} \\
(0.062)\end{array}$ \\
\hline & 13 years or more & $\begin{array}{l}0.141^{* * *} \\
(0.028) \\
\end{array}$ & $\begin{array}{l}0.109 * * * \\
(0.053) \\
\end{array}$ \\
\hline \multirow{4}{*}{$\begin{array}{l}\text { Children under } 18 \\
\text { years old }\end{array}$} & All in Ouagadougou & 1 & 1 \\
\hline & All outside Ouagadougou & $\begin{array}{l}0.543^{* * *} \\
(0.106)\end{array}$ & $\begin{array}{l}0.504^{* *} \\
(0.144)\end{array}$ \\
\hline & $\begin{array}{l}\text { Some in and some outside } \\
\text { Ouagadougou }\end{array}$ & $\begin{array}{l}0.341^{* * *} \\
(0.074) \\
\end{array}$ & $\begin{array}{l}0.445 * * \\
(0.154) \\
\end{array}$ \\
\hline & No children & $\begin{array}{l}0.963 \\
(0.192) \\
\end{array}$ & $\begin{array}{l}0.706 \\
(0.210) \\
\end{array}$ \\
\hline \multirow[t]{3}{*}{ Place of origin } & Urban area in Burkina Faso & 1 & 1 \\
\hline & Rural area in Burkina Faso & $\begin{array}{l}0.775 \\
(0.155) \\
\end{array}$ & $\begin{array}{l}0.645 \\
(0.210) \\
\end{array}$ \\
\hline & Abroad & $\begin{array}{l}1.047 \\
(0.260) \\
\end{array}$ & $\begin{array}{l}1.050 \\
(0.376)\end{array}$ \\
\hline \multirow{3}{*}{$\begin{array}{l}\text { Time elapsed since } \\
\text { arrival in } \\
\text { Ouagadougou }\end{array}$} & $1-2$ years & 1 & 1 \\
\hline & $3-5$ years & $\begin{array}{l}0.169 * * * \\
(0.031) \\
\end{array}$ & $\begin{array}{l}0.223^{* * *} \\
(0.054) \\
\end{array}$ \\
\hline & 6 years or more & $\begin{array}{l}0.217^{* * *} \\
(0.046) \\
\end{array}$ & $\begin{array}{l}0.349 * * * \\
(0.094) \\
\end{array}$ \\
\hline \multirow{2}{*}{$\begin{array}{l}\text { Type of } \\
\text { neighbourhood }\end{array}$} & Formal & 1 & 1 \\
\hline & Informal & $\begin{array}{l}0.743^{* *} \\
(0.124) \\
\end{array}$ & $\begin{array}{l}0.431^{* * *} \\
(0.120) \\
\end{array}$ \\
\hline \multirow[t]{2}{*}{ House owner } & Yes & 1 & 1 \\
\hline & No & $\begin{array}{l}0.606 * * \\
(0.146) \\
\end{array}$ & $\begin{array}{l}0.472 * * * \\
(0.136) \\
\end{array}$ \\
\hline \multirow[t]{3}{*}{ Standard of living } & Poor & 1 & 1 \\
\hline & Middle & $\begin{array}{l}1.078 \\
(0.208) \\
\end{array}$ & $\begin{array}{l}0.925 \\
(0.208) \\
\end{array}$ \\
\hline & High & $\begin{array}{l}1.756 \\
(0.635) \\
\end{array}$ & $\begin{array}{l}0.983 \\
(0.495)\end{array}$ \\
\hline
\end{tabular}




\begin{tabular}{|l|l|l|l|}
\hline Household head & Yes & 1 & 1 \\
\cline { 2 - 4 } & No & 1.122 & $0.565^{*}$ \\
& $(0.212)$ & $(0.181)$ \\
\hline Constant term & & $\begin{array}{l}2.314 \\
(1.203)\end{array}$ \\
\hline $\mathrm{N}=2208$ & & \\
\hline Standard errors in parentheses. ${ }^{*} \mathrm{p}<0.10,{ }^{* *} \mathrm{p}<0.05,{ }^{* * *} \mathrm{p}<0.01$ \\
\hline \multicolumn{2}{|l|}{ Data sources: Survey on the family histories of migrants (2015) and Ouaga HDSS } \\
\hline
\end{tabular}


Table 6. Determinants of physical separation for couples in a union living together in Ouagadougou between 2008 and 2015 (discrete-time event history logistic regression) (weighted results)

\begin{tabular}{|c|c|c|c|}
\hline \multirow[t]{2}{*}{ Variables } & \multirow[t]{2}{*}{ Modalities } & \multicolumn{2}{|c|}{ Odd ratios } \\
\hline & & Gross effect & Net effect \\
\hline \multirow[t]{2}{*}{ Sex } & Men & 1 & 1 \\
\hline & Women & $\begin{array}{l}0.840 \\
(0.285)\end{array}$ & $\begin{array}{l}12.266^{* * *} \\
(7.388)\end{array}$ \\
\hline \multirow[t]{4}{*}{ Age } & $15-24$ years & 1 & 1 \\
\hline & $25-34$ years & $\begin{array}{l}1.400 \\
(0.472)\end{array}$ & $\begin{array}{l}0.469 \\
(0.242)\end{array}$ \\
\hline & $35-44$ years & $\begin{array}{l}2.743^{* *} \\
(1.113)\end{array}$ & $\begin{array}{l}0.802 \\
(0.556) \\
\end{array}$ \\
\hline & 45 years or more & $\begin{array}{l}6.074 * * * \\
(2.564) \\
\end{array}$ & $\begin{array}{l}1.752 \\
(1.236) \\
\end{array}$ \\
\hline \multirow[t]{3}{*}{ Educational level } & None & 1 & 1 \\
\hline & Primary & $\begin{array}{l}0.267^{* *} \\
(0.141)\end{array}$ & $\begin{array}{l}0.374 \\
(0.224)\end{array}$ \\
\hline & Secondary or tertiary & $\begin{array}{l}0.700 \\
(0.288)\end{array}$ & $\begin{array}{l}0.481 \\
(0.293)\end{array}$ \\
\hline \multirow[t]{4}{*}{ Union duration } & $1-3$ years & 1 & 1 \\
\hline & $4-6$ years & $\begin{array}{l}1.916 \\
(0.877)\end{array}$ & $\begin{array}{l}1.119 \\
(0.571)\end{array}$ \\
\hline & $7-12$ years & $\begin{array}{l}5.126 * * * \\
(2.141) \\
\end{array}$ & $\begin{array}{l}1.893 \\
(0.955) \\
\end{array}$ \\
\hline & 13 years or more & $\begin{array}{l}6.704 * * * \\
(2.991) \\
\end{array}$ & $\begin{array}{l}0.485 \\
(0.288) \\
\end{array}$ \\
\hline \multirow{4}{*}{$\begin{array}{l}\text { Children under } 18 \\
\text { years old }\end{array}$} & All in Ouagadougou & 1 & 1 \\
\hline & All outside Ouagadougou & $\begin{array}{l}7.198^{* * *} \\
(2.396) \\
\end{array}$ & $\begin{array}{l}3.051^{* *} \\
(1.421)\end{array}$ \\
\hline & $\begin{array}{l}\text { Some in and some outside } \\
\text { Ouagadougou }\end{array}$ & $\begin{array}{l}1.991 \\
(0.851)\end{array}$ & $\begin{array}{l}0.675 \\
(0.360)\end{array}$ \\
\hline & No children & $\begin{array}{l}1.572 \\
(0.624)\end{array}$ & $\begin{array}{l}1.989 \\
(0.978)\end{array}$ \\
\hline \multirow{2}{*}{$\begin{array}{l}\text { Previous couple } \\
\text { reunification }\end{array}$} & Yes & 1 & 1 \\
\hline & No & $\begin{array}{l}0.022^{* * *} \\
(0.010) \\
\end{array}$ & $\begin{array}{l}0.021 * * * \\
(0.013) \\
\end{array}$ \\
\hline \multirow[t]{3}{*}{ Place of origin } & Urban area in Burkina Faso & 1 & 1 \\
\hline & Rural area in Burkina Faso & $\begin{array}{l}0.328 * * * \\
(0.108)\end{array}$ & $\begin{array}{l}0.329 * * \\
(0.147)\end{array}$ \\
\hline & Abroad & $\begin{array}{l}0.950 \\
(0.378)\end{array}$ & $\begin{array}{l}0.595 \\
(0.347)\end{array}$ \\
\hline \multirow{3}{*}{$\begin{array}{l}\text { Time elapsed since } \\
\text { arrival in } \\
\text { Ouagadougou }\end{array}$} & $1-2$ years & 1 & 1 \\
\hline & $3-5$ years & $\begin{array}{l}0.899 \\
(0.302)\end{array}$ & $\begin{array}{l}1.030 \\
(0.454) \\
\end{array}$ \\
\hline & 6 years or more & $\begin{array}{l}1.006 \\
(0.371)\end{array}$ & $\begin{array}{l}1.528 \\
(0.777)\end{array}$ \\
\hline \multirow{2}{*}{$\begin{array}{l}\text { Type of } \\
\text { neighbourhood }\end{array}$} & Formal & 1 & 1 \\
\hline & Informal & $\begin{array}{l}0.604 * \\
(0.175)\end{array}$ & $\begin{array}{l}0.412 * \\
(0.173)\end{array}$ \\
\hline \multirow[t]{2}{*}{ House owner } & Yes & 1 & 1 \\
\hline & No & $\begin{array}{l}1.342 \\
(0.462)\end{array}$ & $\begin{array}{l}1.383 \\
(0.641) \\
\end{array}$ \\
\hline \multirow[t]{2}{*}{ Standard of living } & Poor & 1 & 1 \\
\hline & Middle & 0.697 & 0.871 \\
\hline
\end{tabular}




\begin{tabular}{|c|c|c|c|}
\hline & & $(0.210)$ & $(0.293)$ \\
\hline & High & $\begin{array}{l}1.926 \\
(0.969)\end{array}$ & $\begin{array}{l}1.146 \\
(0.835)\end{array}$ \\
\hline \multirow[t]{2}{*}{ Household head } & Yes & 1 & 1 \\
\hline & No & $\begin{array}{l}0.231 * * * \\
(0.066)\end{array}$ & $\begin{array}{l}0.136 * * * \\
(0.056)\end{array}$ \\
\hline Constant term & & & $\begin{array}{l}0.090 \\
(0.084)\end{array}$ \\
\hline \multicolumn{4}{|l|}{$N=5624$} \\
\hline \multicolumn{4}{|c|}{ Standard errors in parentheses. ${ }^{*} p<0.10,{ }^{*} p<0.05, * * * p<0.01$} \\
\hline \multicolumn{4}{|c|}{ Data sources: Survey on the family histories of migrants (2015) and Ouaga HDSS } \\
\hline
\end{tabular}

